\title{
Review
}

\section{A duty to resist: When disobedience should be uncivil}

Candice Delmas

Oxford University Press, Oxford, 2018, x + 295pp.,

ISBN: 978-0-19-087219-9

Contemporary Political Theory (2020) 19, S126-S129. https://doi.org/10.1057/s41296018-00296-7; published online 6 December 2018

This is a beautifully written, philosophically astute, and timely contribution to debates about political disobedience. Although congruent with now familiar calls to transcend strict liberal models of civil disobedience, the volume offers an innovative - and oftentimes persuasive - philosophical defense of a broadly conceived moral duty to resist injustice, a moral duty Candice Delmas interprets as covering not just legal protest and civil disobedience, but also 'uncivil' lawbreaking and resistance. As I write, even liberal-minded journalists are categorically condemning militant protestors, e.g., ANTIFA and anarchist activists aggressively confronting Trump Administration officials and right-wing FOX News commentators at restaurants or at their homes, where they sometimes vandalize property (Beinert, 2018). Though she offers no blanket defense of such activities, Delmas' nuanced analysis challenges those seeking to circumscribe justifiable protest to legal or illegal channels, conceived conventionally as public, nonviolent, nonevasive (e.g., of possible legal penalties) civil disobedience exhibiting 'proper' decorum.

To be sure, even liberals like John Rawls condoned militant, potentially uncivil resistance in political orders that could not be characterized as 'nearly just' (Rawls, 1971, pp. 367-368). Delmas goes further: her defense of a defeasible moral duty to engage in uncivil (e.g., covert, evasive, violent, and offensive) lawbreaking applies not just to illegitimate or authoritarian political contexts, but also legitimate - and basically just or democratic - settings: 'My account of political obligations in the face of injustice does not assume a particular conception of legitimacy' (p. 14). Moreover, she insists that we take the idea of a moral duty to resistance seriously and not confuse it with conventional views of civil disobedience as potentially 'permissible' but not obligatory.

Illustrating her argument with carefully chosen examples, Delmas builds on recent philosophical work about political obligation, with most of the volume devoted to showing how influential defenses of the idea of a basic duty to follow

(C) 2018 Springer Nature Limited. 1470-8914 Contemporary Political Theory Vol. 19, S2, S126-S129 
the law can be interpreted as justifying, no less systematically, a principled obligation to disobey the law in the face of injustice. Standard 'duty of justice,' fairness, Samaritan, and associative approaches to political obligation, when properly interpreted, leave substantial room for a moral duty to resistance. Her overall exposition's most striking feature is perhaps the insight that relatively mainstream liberal and democratic accounts can and should be read, against the grain, as buttressing a radical theory of political disobedience. Furthermore, that theory can help those now fighting injustice successfully navigate some dangerous political minefields, as Delmas vividly shows in a thoughtful postscript written in the shadows of the first year of Trump's presidency.

Delmas' book consistently weighs in on many longstanding debates with great political acumen as well as impressive philosophical learning. A major contribution destined to shape discussion for years to come, it is also refreshingly accessible and thus can be suitably assigned to undergraduates in a variety of academic fields. Significant books, of course, always invite critical responses and novel questions; Delmas' is sure to do just that. As a tentative contribution to the debate, I focus on two interrelated issues.

First, Delmas promises a unified theory of political resistance relevant to both legitimate and illegitimate political contexts, pushing back - as noted - against the conventional tendency to limit justifiable 'uncivil' lawbreaking to unjust and illegitimate political settings. However, her own examples often capture scenarios where it seems difficult to characterize key features of the political-institutional context as basically legitimate, democratic, or just. When 'hacktivists' maintain their anonymity and damage computer servers, for example, they justify their actions by highlighting the undemocratic, secretive, and unjust ways in which most (supposedly) liberal governments make the relevant policies, and then effectively shroud their decisions from public scrutiny. When refugees and immigrants are rounded up into repressive detention camps where basic rights are denied and their lives placed at risk, it becomes hard to see how they have a reasonable chance to take advantage of some 'minimally just' political mechanisms. At some junctures, Delmas' argument moves toward effacing any meaningful distinction between basically legitimate and illegitimate regimes: 'Most historical and current polities fall somewhere between the two extremes' of clearly legitimate and illegitimate regimes (p. 175). Contemporary liberal societies, she accurately suggests, are characterized by 'nonideal, all-too-often-unjust conditions' (p. 135).

That analytic move offers some potential advantages, especially in light of deeply authoritarian and anti-egalitarian trends at work in all existing liberal states. Rawls was surely wrong to view the US (and other major liberal democracies) as 'nearly just,' a key reason why those seeking political change, in his view, were to limit their actions to civil disobedience. But perhaps his basic point that militant, uncivil protest only made sense outside 'nearly just' political contexts still makes sense: the problem is that we have yet to create a 'basically' or 'nearly just'

(C) 2018 Springer Nature Limited. 1470-8914 Contemporary Political Theory Vol. 19, S2, S126-S129 S127 
political order. Nonetheless, it may remain normatively useful to maintain some analytic distinction between a basically legitimate or just and an illegitimate or unjust political order. Even if that distinction should chiefly be interpreted as anticipating the just and democratic order we have yet to establish, the core intuition that a legitimate and just order should not in principle require of citizens that they engage in secret or violent protest (e.g., vigilantism, violent revolution) remains appealing. In a basically just order, at any rate, one would hope that citizens need not be forced to hide or risk their lives in order to correct injustice.

Second, Delmas occasionally moves too fast in discarding conventional ideas about civil disobedience. Following David Lyons, she does not do proper justice to the deeply 'legalistic' impulses of Gandhi or King, both of whom favored civil disobedience, partly because they interpreted it as best able to provide evidence of the lawbreaker's abiding respect for law (pp. 23-27). It is misleading to claim that US civil rights groups 'adopted their particular style of civil disobedience for [exclusively] context dependent, tactical purposes' (p. 27). More fundamentally, she overstates liberal theorists' preference for civil disobedience as necessarily requiring nonoffensive decorum. Though the emphasis on respectability was crucial to Gandhi and King, many liberal philosophers have rejected it, instead opting to reinterpret 'civility' as referring to the politically motivated lawbreaker's basically political or civic orientation, for example, or her commitment to some sense of the common good (Scheuerman, 2018, p. 45).

Unfortunately, this misreading shapes Delmas' sharp juxtaposition of civil to uncivil disobedience and gets in the way of examining key questions. Even some relatively stodgy 1960s liberal theorists defended the possibility that civil disobedience might prove politically offensive and perhaps even include forms of 'violence,' e.g., violence against property or things, as long as no immediate harm to concrete persons ensued (Scheuerman, 2018, pp. 44-47). Liberals and their critics debated at length whether it made sense to view civil disobedience as including features of what Delmas now describes as 'uncivility.' Grouping protests that range from minor acts of vandalism to organized revolutionary violence under the broad rubric of 'uncivility,' Delmas cannot perhaps seriously consider the possibility that 'offensiveness' or even some types of violence can cohere with core features of civil disobedience, as interpreted by a range of iconic political figures and important philosophical voices. Perhaps this is why she is ultimately driven to identify limits to uncivil disobedience, limits that seem reminiscent of those endorsed in standard views of civil disobedience. Even those engaging in uncivil resistance are obliged to 'act with respect for other people's interests, including... their basic interests in life and bodily integrity,' and they should also be expected to 'seek the least harmful course of action feasible' (p. 49). Nonviolent disobedience should generally be favored (p. 88). Are these echoes of civility interpreted as a commitment to the common good, and perhaps even some minimalist version of nonviolence? Militant protestors are also tasked with 
respecting others' 'interest in protection by a stable, secure system of rights,' (p. 49), a test that seems akin to the familiar notion that legitimate (civil) lawbreaking requires some demonstration of respect for law. Uncivil disobedience, it turns out, may not always be all that different from civil disobedience. This point tends to get submerged in Delmas' otherwise brilliant book because of its tendency to provide an overly narrow interpretation of what civil disobedience historically and philosophically has meant, even for some liberals.

\section{References}

Beinert, P. (2018) Left-wing protests are crossing the line. The Atlantic (16 November 2018). https:// www.theatlantic.com/ideas/archive/2018/11/protests-tucker-carlsons-home-crossed-line/576001/. Accessed 23 November 2018.

Rawls, J. (1971) A Theory of Justice. Cambridge: Harvard University Press.

Scheuerman, W. (2018) Key Concepts: Civil Disobedience. Cambridge: Polity Press.

William E. Scheuerman Indiana University, Bloomington, IN 47405, USA wscheuer@indiana.edu 